\title{
Digital Platforms for Postal Services in EU and Japan
}

Maciej Lewandowski, Logistics Operations Department Polish Post, Poland

Paweł Młodkowski, School of International Liberal Arts, MIC, Japan

Marek Wróbel, Institute of Logistics, WSB University in Poznań, Faculty in Chorzów, Poland

$\Gamma$

Crossef http://dx.doi.org/10.5755/j01.eis.0.13.22897

The aim of this paper is to present and compare utilization of digital platforms used by national postal operators in the EU and Japan. Tasks include a biased review of digital platforms introduced recently and operated by national posts in several European Union countries and in Japan. Authors chose the most interesting cases, including those deemed as the most successful, those that failed, and the most modern ones. The next task is a comparison of diverse European experience with modern solutions introduced by the Japan Post. Methods used for delivering the study include direct interviews with Japan Post officials and systematic review of official documents and announcements by national post operators in European countries. European Union Member States, and their national postal operators seem to be well ahead of Japan in the way modern technology is utilized in the process of providing traditional (and new) postal services. Paper makes successful attempt to show how representative national postal operators benefit from advanced Information and Telecommunication technology and by replacing the manner in which postal services are rendered. There are numerous successful cases of digital platform implementation, like those from Denmark, France, Czech Republic, and Poland, among others. One may find interesting insight into reasons for failed case from Italy among conclusions, at the end of the paper. Environmental issues are also addressed, along with e-government issues. It happens that European Union postal operators optimize their operations with modern technology in the form of digital platforms in a much wider scope than the Japan Post. Japanese organizations deal with extremely challenging geographic conditions. This, in turn, should motivate much more advanced optimization by the means of solutions enabled by digital platforms. European postal operators have been recognized as leaders in maximizing benefits offered by digital platforms so far.

KEYWORDS: modern postal services, digital postal services, public e-services, e-government, Japan, EU.

The digitisation of the economy and society is one of dynamic changes taking place today. Digitisation is also a continuous process of convergence of the real and virtual world, which is becoming a driving force for innovation and change in most sectors of the economy (Gajewski et al. 2016, 11; Castells 2010, 5; Cetina and Bruegger 2002, 905; Chaffey 2016, 10; van Dijk, 2005,156, Tian and Stewart 2006, 560). According to Oxford English Dictionary, the concept of digitisation includes now the adaptation and growth of the use of digital or computer technologies by organisations, institutions, economic sectors or countries (Sobczak 2013,280). McKinsey describes digitisation as operations utilizing digital tools aimed at increasing productivity and growth. Digitisation facilitates productivity growth in four ways (McKinsey 2016):

- first and foremost through process optimisation,

- expanding sales,

- innovative products, and

- more efficient use of human capital.
EIS 13/2019

Digital Platforms for Postal Services in EU and Japan

Submitted 03/2019

Accepted for

publication 10/2019

Introduction

ktu

European Integration Studies No. 13 / 2019, pp. 117-130 doi.org/10.5755/j01.eis.0.13.22897 
The emergence of the global internet network was a breakthrough for digitisation of the economy. The Internet was initially used by scientists and military personnel. Its development was accelerated then by private providers of services and websites. The further development of new technologies, such as Java or WAP, allowed the creation of websites and the development of mobile services. At the end of the 1990s, the Internet entered the Web 2.0 era and became a collection of web services, thanks to which the users of a given website can create content themselves. At the turn of the millennia, the era of Web 3.0 began with an increase in data transfer speed and the development of search engines, but also the ability to transfer not only text, but voice and video. The current Internet protocol IPv4 enabled to create 4.3 billion network addresses, while the new IPv6 protocol will allow to create 349 billion addresses (Śledziewska et al. 2017, 12). In turn, wireless Internet has become the most commonly used way of connecting to digital infrastructure. It also accelerated the connection of about 3.4 billion users to the Internet in 2016. This technology generates over $2 \%$ of global GDP. It affects the functioning of $1 / 3$ of the world economy and has a significant impact on the work of $70 \%$ of all employees. Based on the investment plans, it can be estimated that by 2025 the number of users will be approximately 4.3 billion (McKinsey 2013). Undoubtedly, laptops, smartphones and tablets are currently used to handle many everyday matters via Internet. Online platforms act as intermediaries between market participants, who wish to carry out transactions. Such platforms use web applications based on algorithms that connect users, consumers, and sellers. According to a research conducted by the European Commission, platform users recognized their main benefits, as:

- facilitating access to information,

- improving communication and online interaction,

- wider range of choice of products and services,

- access to new markets, and

- new business opportunities.

Convenient communication provided by online platforms reduces the cost of reaching consumers by sellers. Costs of finding information on products and services bear by consumers decrease also. Consumers benefit from recommendations and reviews issued by other users. It should be noted that online platforms are diverse, especially in terms of their purpose and facilitated activities. But that is precisely why, the European Commission, by planning the regulation of the Unified Digital Market in the area of digital platforms, has omitted the specification of their precise definition. Instead, it listed their most important types: advertising platforms, auction platforms, search engines, social networking platforms, price comparators and payment systems. Internet platforms are therefore based on a new all-encompassing business model that enables interplay of demand and supply through the use of modern technologies. With their help it becomes possible to carry out banking transactions, make purchases, settle official matters, or purchase postal services. Postal services provided through digital platforms are often described as "digital mailboxes", "digital boxes" or "certified electronic mail", and are used by EU governments for correspondence and exchange of documents with citizens. It is worth noting that the costs of handling digital correspondence, amounts at about $20 \%$ of the costs of traditional correspondence. What is also important for public institutions is that digital correspondence is legally binding. This means that digital box systems provide indisputable evidence of receipt and dispatch of documents, secure their content, but also ensure authenticity of origin through advanced authentication systems. As a result of the European Parliament and Council Regulation eIDAS of 2014, a Registered Electronic Shipment has the same legal status as a registered letter (On electronic 2014). The ease of access to the digital mailbox is also important, as it can be accessed from almost anywhere via the Internet. There were 5 million individual users of the digital 
mailbox of the French Post Office already in 2015. 600 thousand companies and 5 million citizens (and 11 million including people living in Norway and Sweden) were using the digital mailbox of the Danish Post Office.

The aim of this article is to present technological trends in the digitisation of postal services and models of digital platforms defined as digital mailboxes created by national postal operators in the European Union and in Japan. We compare Japan Post solutions with Envelo, the most modern digital platform of postal services by Poczta Polska S.A., a national operator with 460 years of tradition, enjoying social trust and already having experience in creating new technologies, not only in delivering traditional letters and parcels.

The study was carried out using direct interview with representative of Japan Post, and an analytical method, consisting of a targeted study of the publications also available on the Internet. It was based on systematization of knowledge in the field of solutions for e-government services. On the basis of the analysis of source texts, the solutions applied by the defined postal operators in the European Union were cast against Japan Post achievements in this respect. The comparison was conducted from the point of view of benefits for individual, institutional and business customers.

In 2015, the European Commission has taken the initiative to create a Unified Digital Market. The Unified Digital Market in the European Union means:

- the development of economic cooperation in e-commerce,

- the simplification of VAT accounting in international transactions,

- a new system of personal data protection in the network,

- a reform of copyright law allowing the development of new types of services, and the extension of the Internet infrastructure, as well as

- the improvement of cyber security.

The establishment of the Unified Digital Market is intended to stimulate EU economic growth, to become the substructure of the economy based on knowledge and innovation, and to combat social exclusion. On 6th of May 2015 the strategy of the Unified Digital Market for Europe was adopted. It included 16 priorities deemed necessary to achieve its objectives. The European Commission concluded in 2015 that removing existing barriers will encourage cross-border trade. It was estimated that once legal obstacles are removed, an additional 122 thousands of enterprises will start cross-border online sales. This could increase intra-EU exports by around $€ 1$ billion. Such additional competition in retail trade should result in lower prices in all member states, estimated at, on average $-0.25 \%$ at the Union level. Consumer demand should increase as a result of reduced prices. Consumer confidence would also improve through the unification of laws in the Union. Household expenses, which show a level of consumer welfare, would increase by $+0.23 \%$ on average in each of the EU member states. This represents an increase of this macrovariable by almost $€ 18$ billion. The number of consumers, who would start buying products from abroad via the Internet, would rise from 7.8 to as much as 13 million. The average annual expenditure of each consumer buying products from abroad via the internet would also increase by $€ 40$ per year. This increase in demand would have a direct impact on main macroeconomic variables in each Member State. The European Commission expects therefore a systematic increase in the Union's real GDP by around $€ 4$ billion per year. Introduction of the Unified Digital Market is expected to provide the EU with additional $€ 416$ billion per year. According to McKinsey \& Company analyses, Western Europe has so far utilized 12 percent of its digital potential, Poland has reached just 8 percent, while the entire American economy has utilized 18 percent. This means that digitisation has just started.

\section{Methods}

Unified Digital Market in the EU 
In 2015, there were about 14 million fixed-line and mobile Internet users in Poland in total. Throughout Europe, 315 million users use the Internet every day. On average, $31.6 \%$ of people in Europe benefited from fixed-line Internet access in 2015. The highest saturation of these services is in the Netherlands and Denmark, with over $42 \%$. In 2015, nearly $19 \%$ of population in Poland have access to fixed-line broadband Internet services. Over just 2015, Poland recorded an increase by about 0.9 million in this respect. The number of mobile Internet users also grew dynamically from 5.8 million in 2014 to 6.7 million in 2015. For several years Poland has been one of the leaders in Europe in terms of saturation with services of mobile network access. In 2015, Poland ranked 5th in the EU with a result of over 94\% (Office 2015; 2016). Saturation in Poland was therefore 19 percentage points higher than the EU average. Finland has been the European leader in this respect, with a score of almost 139\% in 2015. (Office 2015, p. 10). However, the McKinsey Digitisation Index shows, that the level of digitisation in Poland is by $34 \%$ lower than in Western Europe (average for France, the Netherlands, Germany, Sweden, the United Kingdom and Italy). McKinsey's analysis also shows that, due to digitisation within the coming decade the value-added of the entire economy in Poland could increase by $13-22 \%$. Digitisation would reduce the productivity gap by $12-21 \%$, compared to the most advanced Western European economies, and by 27-47\%, compared to the EU-15 (McKinsey 2016, 7). Optimistic is the fact that in terms of "digital demand" (which is a measure of digital technology utilization rate), Poland has not been lagging behind Western Europe - the gap here reaches only $16 \%$. This means that the Polish businesses have utilized digital technology to contact customers, suppliers, and partners to a similar extent, as Western European firms. There is still a low initial stage of development in the field of online transactions, online services for customers, and communication with the use of digitally advanced technologies. However, a key challenge for Poland is the supply of digital resources, where the gap between Poland and Western Europe is at $44 \%$. This means that companies in Poland invest much less in assets, and employ fewer specialists in jobs of a digital nature than in Western Europe. With the intensification of investments aimed at building digital assets and creating related jobs, the country's position in this respect is likely to improve. It should be noted that 7.2 million people in Poland graduated from higher education institutions, between 1998 and 2012. This means that the country has the largest resource of highly educated labour in the EU. 800 thousands students graduated in science, while 185 thousands graduated from IT programs. In these two particular categories of higher education Poland ranks third in the EU, after Germany, and France. Poland has also the largest outflow of educated labor in the European Union. According to 2013 records, around 280 thousand people with a university degree had lived in another EU or EFTA country for up to 10 years already. Unfortunately, the outflow of digitally-skilled workers increases the productivity gap, and weakens the Polish economy. Although the Polish economy laggs behind Western Europe in terms of digitisation, it has strong foundations for further digital growth. There are talented workers plus Poland holds competitive advantage resulting from lower labour costs than in other EU countries (McKinsey 2016, 17). A very special place and role in the process of digitilization of a national economic system belongs to national postal operators. The EU has been a global leader in regard to utilization of modern solutions in this regard. Platforms, created by postal operators, are already being used by the governments of individual EU countries for correspondence and exchange of documents with citizens. An important stimulus for the development of these digital platforms was Regulation of the European Parliament and Council (EU) No. 910/2014 of 23 July 2014 on electronic identification and trust services for electronic transactions in the EU internal market (the so-called eIDAS regulation). The regulation has introduced a number of solutions aimed at increasing trust in transactions and on-line communication between central, or local, government offices, businesses, and citizens. Importantly, the solutions adopted in the EU are intended not only to sup- 
port the development of the e-trust services sector in Europe, but also to improve the handling of various issues by citizens or businesses between individual countries within the EU. This should lead to shortening of various processes and reducing the amount of documentation accompanying these processes. Positive environmental impact seems undeniable. The most important solutions introduced by the eIDAS regulation are as follows:

- an electronic seal - which is intended to ensure the authenticity and integrity of the sent documents, an electronic time stamp - which is treated as an equivalent of a postal stamp to confirm the existence, preparation and sending of the document at a given time;

- an electronic signature - an equivalent of a traditional signature, constituting the confirmation of the authenticity of the documents bearing it;

- a recorded electronic delivery - an equivalent of registered letter, provides evidence of the sending and receipt of the sent correspondence.

All of these solutions exist on several levels, the most important of which is the so-called qualified level. Consequently, a document sent by the public administration using qualified registered electronic delivery, and bearing a qualified electronic seal, a qualified electronic time stamp, and a qualified electronic signature is identical to the original postal service and has the same legal effects. This is very important solution for implementing e-government (ec.europa.eu 2014; $2015 ; 2016)$.

In 2001, a system for electronic communication was launched in Denmark to connect public institutions, entrepreneurs, and citizens. The e-Boks digital box is a version of the digital mailbox based solely on the internet channel. The e-Boks digital box is created from the very beginning by a public and private entity, i. e. Post Danmark and Nets, a provider of payment services, payment cards and information technology. To set up a box one needs a digital NemID signature. It can be obtained in several ways: online (using a passport or driving licence, if the user's address exists in a national register), by public administration units (here one needs a personal authorisation) or via Internet banking. E-Boks is an electronic inbox, in which a citizen cannot initiate any shipment on his/her own. This means that from citizen point of view, usage restricted to receiving messages from a sender and responding to these, in which the sender gave an opportunity to respond. The messages are addressed to citizens using a special personal CPR identification number. In order to receive such correspondence, a receiver must subscribe to a given sending entity (public administration authority, or company), and the sender must approve it. An important feature of e-Boks is that the received messages are subject to lifelong archiving. It is also important for citizens that e-Boks enables to upload, and store, their own private documents. The fact, that there is a single password for accessing many different types of services and official matters in one place, is an additional advantage of the system. In addition, e-Boks users have an option to allow family members, or co-workers, for accessing to their mailbox, with specification, which type of mail can be accessed. It is worth noting, that all Danish municipalities are sending out messages to citizens via e-Boks. Many other institutions such as banks, insurance companies, energy companies, telecommunications companies follow the same route. This system is obligatory for entrepreneurs and the government has supported its development from the very beginning. It was announced in 2014, that it would be the responsibility of every Danish citizen to own an e-Boks box. By the end of 2015, it was obligatory for everyone to use an electronic channel for contacting with public institutions. About $70 \%$ of citizens joined the system before it became obligatory. It is worth noting, that the awareness of functioning of this system in 2014 among citizens over 15 years of age was $97 \%$. This is a proof of an effective information campaign. However, Danish citizens have still the choice of how they wish to receive messages: electronically, or traditionally,
Selected models of digital platforms of postal operators in the European Union 
and the decision can be changed. e-Boks has been used by 600 thousand companies and 5 million Danes (11 million including people living in Norway and Sweden). Mail cost is by $80 \%$ lower than in case of traditional correspondence. 308 millions of documents were sent in this system already in 2015, saving more than 5000 tons of paper (about 85 thousand trees). $86 \%$ of users are satisfied with the operation of this digital box and $77 \%$ consider it a great facility to receive all correspondence from both the public and private sector in one place. E-Boks has been used by 1300 new users daily. Thanks to e-Boks consumers saved around $€ 214$ million in postal services in 2012. This digital platform generated approximately $€ 13.5$ million in revenue and a profit of around $€ 2.2$ million in 2012. In the view of the above, it can be said, that this system has been successful in Denmark (e-boks 2018; Piskorski 2016, p. 8; Piskorski 2017, p. 7-8).

Another successful case, since 2009, has been a digital platform for document exchange in the e-administration programme in the Czech Republic, named Datove Schranky (DS). The system is owned by the Ministry of the Interior. Its operator is Czech Post Office. The main objective of DS is to reduce communication cost between authorities, citizens, companies, and public administration. The most important task of DS is to increase the speed, comfort and reliability of communication while ensuring safety. DS handled more than 186 million electronic shipments and around 1.2-1.3 million transactions per week between July 2009 and the end of 2014. The number of active accounts in the customer system reached over 585 thousand. Data boxes (DS) are obligatory for all public administration institutions (about 8 thousand), notaries and repossession agents (about 600), as well as for all companies and institutions with legal personality. The DS platform may be operated by a natural person, or a person running a business activity, but participation is voluntary. For public administration authorities, notaries and repossession agents having data boxes is free of charge. For natural persons and those, who run a business activity, the creation of a data box takes place after an application has been submitted by the person concerned, and it requires a visit to the Czech POINT office. A fee is around 1 euro.

Sending a document consists of logging into the DS, placing in the data box a message with maximal size of $10 \mathrm{MB}$ and assigning the destination address, along with the shipment parameters. Assigning the address means giving the user of target mailbox the right to access the document. Parameters of the shipment are standard postal procedures, such as receipt proof and other. Additional services such as a postage with paid return reply, or shipment at the expense of the recipient are chargeable. A standard document is removed after 90 days, but there is an option to buy an additional area (so-called Trezor), in which the data is permanently stored. If the receiver doesn't log into his/her mailbox within 10 days of the date of receipt of the document, the document shall be deemed to have been delivered, which shall have the same legal effect as the receipt of a traditional postal parcel.

Czech Post Office's revenue from the Datove Schranky system comes from a contract with the Ministry of the Interior, which regulates fees for all users from the state administration, courts, notaries and repossession agents, and from fees paid by commercial users. The use of DS is obligatory for state administration bodies, and entities financed by the State Treasury. The average cost per transaction fell to below $€ 1$ in 2012. The DS and Czech POINT systems (National Terminal for the Delivery of Confirmed Information - Ministry of the Interior) are complementary due to sales channels, and the manner of service provision. However, Czech POINT uses a paper-based interface and requires a personal visit to an operating point, while DS is a completely electronic system. The interdependence of the two systems (DS and Czech POINT) consists in ensuring by Czech POINT the functionality of documents conversion from electronic to paper form and vice versa (authorized conversion). More than 28.5 million documents were processed in this way since its launch in June 2009 till November 2013. Czech POINT is used to create user 
accounts in Datove Schranki. There has been an improvement in the efficiency of functioning of public administration bodies, while costs were reduced. From the beginning, Czech Post Office has played one of the leading roles in implementing these projects: it is the most active of all Czech POINT system operators. Although it has only 980 out of over 7000 Czech POINT service points, it processes over $52 \%$ of documents, and is the sole operator of the Datove Schranky system by law. Czech POINT services remain stable at about 150 thousand documents per month. The total volume of Czech POINT revenue in 2012 for all system operators amounted in total to approximately EUR 7.6 million, of which Czech Post's revenue amounted to approximately EUR 4.1 million and the gross margin on sales to approximately EUR 3.8 million. The digital platform Datove Schranky brings more revenue to the Czech Post Office. The Ministry's fees alone were on average around €178 million per year (net excluding VAT) for the period 2010-2012. Thanks to the provision of e-administration services, the Czech Post Office earns therefore revenues and builds up its leading position on the market of electronic services in the Czech Republic. The total revenues of Czech Post Office from e-administration services account for $5 \%$ of the total revenue of Post Office. Their profitability is much higher (at about 27\%) than the rest of Post Office's activity, which is less than 1\% (mojedatovaschranka 2018; vlada.cz 2018).

A digital mailbox offered by the French Post Office (La Poste) is nothing more than an ordinary mailbox, in which an account is created using the online channel. However, the French Post Office has introduced a verified digital identity called Digital Identity. If the user of La Poste's box sets up, and verifies his Digital Identity, he/she has then a possibility to send registered letters with standard additional services (e. g. time stamp marking). To set up Digital Identity, a user fills in an online registration form. Afterwards, it is confirmed with the SMS code. At the time of registration the day is selected, on which it will be verified in person, because verification is made by a postman. After verification by a postman, the user receives a Digital Identity. This whole process of account creation, and verification, is completely free. The French Post Office's digital box offers the possibility of two-way exchange of correspondence, and in the case of Digital Identity holders, it is also possible to send and receive electronic registered letters with the possibility of choosing the delivery method: paper (hybrid) or electronic. When the sender sends a registered letter, he/she fills in a form with the recipient's e-mail address (in the French Post Office domain) and his/her own address. Then, the system checks, if the given addressee has a confirmed digital identity. If the addressee has one, the letter is sent electronically - otherwise hybridly. Electronic letters may only be sent to other holders of Digital Identity. Hybrid letters can be sent only to recipients residing in France, Corsica, the French overseas departments, and Monaco. The box can be integrated with the Digiposte, i.e. the electronic document exchange box. Digiposte enables also to archive documents and share them with other users. The free storage space is $5 \mathrm{~GB}$, but the French Post Office provides a chargeable additional space (service-public.fr 2018; atlantico 2018). The exchange of documents is a free service for their recipients, because the entire cost is borne by the sender. QR codes containing key document information are added to the documents. Digiposte offers a dedicated free DIGICheck application for reading these codes. Documents are kept for a specified period of time. 11 thousand national and 70 thousand local services available in the service-public.fr system were carried out using this digital mailbox system in 2015. This platform had 5 million individual user accounts already in 2015.

An interesting case of failure of digital platform for postal services one can find in Italy. Italian government created a law in 2009, which was the starting point for the PostaCertificat@, a digital platform project based on PEC solutions (Certified Electronic Mail). PEC is a service provided by many different operators, typically under annual subscription model. Prices start from $€ 5$ and depend on the size of the box and on the daily limits of messages sent, and some additional op- 
Envelo - a modern digital platform of services offered by Poczta Polska tions (e. g. SMS notifications). The PEC system was supervised by Italian government, which set technical and functional standards. The operators of this system may be entities that pass certification and meet all standards. Italian law imposes an obligation on a specific group of entities to use the PEC: companies, businessmen, and public administration authorities. The message sent with PEC were equivalent to a registered letter. In the case of PostaCertificat@, the provider of free accounts for communication between public offices and citizens, was the Italian Post Office (Poste Italiane). It was, because in 2014, after more than 5 years of operation, the project was closed down, due to low interest, and high costs of operations. By December 2014 Italians have established just over 2.1 million accounts in the PostaCertificat@. Since Posta Certificat@ platform was limited only to communication between citizens and public administration, most citizens preferred to use the "standard" PEC version of other operators providing more of other complimentary services. The low activity of users of this platform (as much as $82 \%$ of the users sent never messages) and high costs of maintenance, and development, (the government spent 18 million euro) resulted in its closure.

Fast developing e-commerce and common access to fixed-line, and mobile, Internet force dynamic changes towards digitisation also in the postal services market. National postal operators place great emphasis on the development of commercial e-services and support for e-government initiatives. Postal services must provide citizens with maximum convenience and secure access to online products. In 2012, Poczta Polska S. A. established a subsidiary company, Poczta Polska Digital Services, in order to digitise its own services. It created Envelo platform. It is one of the most modern digital postal services platforms in Europe. The platform provides convenient access to comprehensive, secure and trusted postal e-services using Internet-connected fixedline and mobile devices. Envelo allows for using postal services anywhere and anytime during the day. Envelo offers services that utilize hybrid solutions providing access to traditional online postal services and fully digitalized services.

Since 2013, Envelo has offered three basic e-products: neostamp, neocard and neoletter. A neostamp, is a sold online postal stamp secured by data matrix code for self-printing. After the online purchase one can print it on a sheet of paper, self-adhesive label or directly on the envelope. Neocard is the same as a postcard sent over the Internet and delivered to every place in the world in print. A sender can attach his/her own photo, or use a photo gallery available on Envelo platform. The neocard is sent with a free application to mobile devices running on Android, iOS or Windows Phone systems. It should be mentioned here, that using the application, one can also use traditional post services, such as: search on the map for a post office or letterbox in the selected location, check the postal code or order a Pocztex courier, and then follow the shipment. Neoletter is equivalent to a traditional letter that a user prepares and sends via Envelo platform. Content of the letter is filled in, or attached as a PDF file, recipient data is added, and the standard, in which the leter should be delivered is selected: economical or priority. Thus, the neoletter is sent on Internet, and delivered to the addressee in a traditional manner: printed in an envelope. A mailman will deliver neoletter directly to a postbox of a designated person, company or bureau.

Envelo platform offers also a dedicated service for exhibitors and recipients of invoices. Since 2014, further e-services have been implemented, such as a neoinvoice and mass neoinvoice. This e-service makes it possible to send all invoices over Internet, regardless of the planned form of delivery: electronic or printed. The recipients of electronic neoinvoices are customers of companies, who can receive, view and archive them in their neoinvoice box. The mass neoinvoice is intended for customers sending over 100 thousands invoices. A dedicated portal is tailored to customer needs through the management of a single shipment and various correspondence 
templates. The e-invoices will be sent to a special inbox on Envelo - Neoinvoices platform. Those invoices that are to be delivered in the traditional way, will be automatically printed and enveloped, and then delivered by a postman to the letterbox. This service is used, among others, by PGE Obrót SA - the largest power supplier in Poland, who sent in 2014 over 6 million electronic documents this way.

In 2014, Envelo introduced neostamps for registered mail with additional services supporting the dispatch of registered mail. There also were made available neostamps for foreign letters and personalised neostamps, which enabled individualisation of the message also in the unique form of a traditional postal stamp. In the first year of this particular service (i.e. 2014), users of Envelo purchased 1 million neostamps and 90 thousand neocards were sent. Nearly 30 thousand users were registered on Envelo platform, while the mobile application was installed by over 40 thousand smartphone and tablet owners.

Envelo Box is a very important element of Envelo platform. It facilitates the process of public administration digitisation. This digital mailbox allows for sending messages from a trusted account marked with the Digital Postal Stamp. The box is a carrier of the e-identity service, which allows for authenticating the user. The Digital Postal Stamp is a guarantee of the authenticity, and integrity, of correspondence, as well as a confirmation of the time of sending and receipt. It should be noted, that Envelo guarantees a very high level of data security through access control in all layers and repository encryption. In security tests of the reputable Qualys SSL LABS Company, Envelo platform received A+ rating. At present, in the scope of Envelo Box, every logged in citizen can be granted the status of a Trusted Account without any charge, and can have access to another service - an electronic neoletter. The condition is a one-off proof of identity at the post office, by presentation of an identity card or passport. If a user runs a sole proprietorship, he/she must also provide tax number and national business registry number. Electronic Neoletter functions only in digital form and is a message sent online only between users of a Trusted Accounts. Although at first glance it may look like an email, the electronic neoletter is much different. Since security is the basis of online communication on Envelo platform, a confirmation of identity of users of Trusted Accounts at a post office gives the sender and the recipient a guarantee, that the correspondence has been sent, and received, by a real person, company, or institution. Holders of Trusted Accounts do not receive any of automatically sent spam from unknown sources or viruses from false addresses. An electronic neoletter can be registered, or unregistered. If the sender chooses the option of a registered letter, he/she will receive to Envelo Box a confirmation of sending, delivery of the message, as well as information about reading it, or rejecting by an addressee. Each of these confirmations is marked with a Digital Postal Stamp. This means that the date shown on the confirmation is authentic, and nobody interfered with its correctness. Such security features are important in business relations, when one sends documents, or offers electronically. Through a network of post offices throughout the country, Polish Post offers Trusted Profile, and its confirmation, by Envelo Trusted Account. After proper verification, a citizen will be able to log in to e-services of public administration via his/her account. Trusted Profile is nothing else but a free, electronic tool for online authenticating one's identity, i. e. the equivalent of an electronic signature. One can easily and quickly handle online many official matters, including filing an application for an identity card, or registering a new business. Trusted Profile is needed for submission of the Standard Audit File for Tax by VAT payers. Authentication of Electronic Identity is the same as presentation of an identity card at a post office, a bank, to a notary, or a lawyer. In this way, the other party confirms the identity of a citizen. After confirmation of identity in the post office, it is possible to use this sequence of numerical signs in relations with public administration. Very important in this regard is an agreement signed in 2016 between the Polish Post and its subsidiary company - Polish Post Digital Services with the Polish Securities Printing House, the provider of an electronic signature. The agreement is about 
Digital platform of Japan Post dissemination of electronic signature via the network of post offices. Another agreement signed in 2016 between the Ministry of Infrastructure and Construction and the Ministry of Digitisation and the Polish Post (Envelo) on strategic cooperation in the process of state digitisation is also very important for supporting public administration in the construction of digital Poland. Nevertheless, the future of Poczta Polska digital platform lies in the full portfolio of digital services tailored to various customer groups (envelo 2018). After presenting EU experience with focus on Polish case, as the most modern digital platform in operation, it is time to compare achievements in this regard by Japan Post.

Japanese postal operator was analysed on a basis of a face-to-face interview with Japan Post top manager responsible for this section. The interview took place in March 2019 in Miyazaki, at the JP Central Office. Japanese economy is considered by many as one of the most advanced and therefore highly digitalized. However, when it comes to digital platforms serving the national post operator, Japan may be considered as lagging behind the European Union. For example, Japan Post does not offer any services that match neostamp, neoinvoice, Envelo Box or searching for a letterbox in a selected location.

Japan Post offers a mobile application that is a restricted and reduced form of the Neocard available in Poland. In Japan customers can create their own postcard with greetings for several special occassions, like the New Year, funeral, summer greetings (SHOOCHU-MIMAI). This platform allows for scanning of previous year postcard mailing address, but its operations are restricted to period from the beginning of November each year to mid-January, for New Year's greetings. The difference from the Neocard is in the location of printing the postcard. Japan Post, after receiving all data for this special service, prints the greetings card in the post office closest to the sender, and then dispatches it through its network to the recipient. No significant savings in terms of transportation costs, or CO2 emissions are achieved this way, unlike in the UE.

There is another service from Japan Post (named: LETAX) that matches closely Neoletter offered by Polish Post. However, there are several differences and limitations. In fact, LETAX is a form of a telegram sent on special occasions. Its uniqueness comes from speed of delivery granted by similar logistics, as in the EU (printing of the message takes place at a post office closest to the recipient). If the service is ordered within the 10 days preceding a special event (like a wedding, final examinations, graduation, etc.) customers may chose exact date and time for delivery of greetings. Customers can chose design of envelopes in which telegram will be delivered. Due to the very nature of telegram, Japan Post grants immediate delivery on the same day, if customers submit the greetings by 15:30. There are some limitations for citizens living in areas on remote small islands, where JP coverage is low. There is an additional service (WEB-LETAX) that is slightly cheaper than the option described above but restricts design of the letterhead and envelopes. It allows for sending the same message (or greetings) to multiple recipients.

Web-Express Mail is another postal service provided via Japan Post digital platform. Users can upload PDF or MsWord files with the content of an intended letter to be delivered on the same day to the receipient, again if the request is made by 15:30. This postal service is covered by a tracking system.

Web Letter by Japan Post is a service to handle the following cases of letters: invoices, invitations, notifications, and Direct Marketing materials. Post office closest to the customer prints the documents provided, and then puts letters in envelopes and dispatches them as regular mail all over Japan using its standard logistics network. The whole process is fully automatic, with no labour involved, and as such is considered as failure-proof. All the three above described services by Japan Post require a prior registration of a customer on JP website. Such registration is free of charge. Japan Post does not offer anything that matches Envelo Box, or anything similar to Trusted Profile solutions. 
E-content certified services by Japan Post seems somehow similar to Digital Postal Stamp that is aimed at confirming the date, and content of a message sent. System accepts MsWord files only due to free access to the content that is subject to certification. Post office closest to sender will check the content, issue a certificate to confirm the content, and then print it and dispatch it via the regular logistics network. This is considered a registered mail, but not express.

ComputerPost service is geographically restricted to only three central post offices in prefectures: Tokyo, Osaka, and Aichi. It offers retrieval of data from any memory device delivered to the three designated post offices in Japan. It allows for sending Direct Marketing materials (with samples of products, like cosmetics for example), and dispatching invoices to numerous customers at the same time.

DMfactory (direct marketing factory) allows for designing direct marketing materials on-line. Customers chose design out of those available in the gallery, and then upload all the required information to-be-included in the advertising leaflet. The minimum number of such direct marketing items is 40 for New Year's card (NENGAtownMAIL), 100 copies for TownPLUS, and 1000 copies of any other types of flyers.

TownPLUS is a dedicated service used often during political campaigns for addressing citizens living in a targeted area. Customers using this service don't need to specify addresses of any recipients. Intended content (leaflets) will be delivered to all people living in a specified part of a town, a village, or a city.

NENGAtownMAIL, which can be translated as "New Year's mail" is similar to TownPLUS. It is available only from the end of December to mid-January. This service is used to send New Year's greetings to people living in a particular part of a settlement. Such greetings are sent by local businesses and contain very often advertisements, special offers and alike that apply for the end-of-the year season.

Japan Post offers few categories of country-specific services. They reflect unique national culture, and facilitate cultivation of Japanese traditions. This is why they are not present elsewhere among national post operators. One should expect few changes to its operations and reforms of Japan Post in the future because there is still capacity of modern technology to reduce costs of operations, and minimize climate impact of this national post operator.

Intended research was completed successfully. Aim of the paper was achieved and presentation of digital platforms of selected countries was complete, and up to date. Comparison of benefits achieved by postal operators, and their customers in respective countries allowed for evaluation and recognizing leadership position.

Summing up the results of the comparative analysis of selected digital platforms of national postal operators in the EU and in Japan one can see clearly market trends. This is not a surprising phenomenon of replacing traditional postal services with modern, digital equivalents. European Union countries seem to record significant success in proliferation of digital platforms for all forms of communication among agents in the national economy, within the EU, and with entities abroad. The comparative case of Japan gives an impression that the underlying economic and social system does not require similar digitalization of postal services, and citizen-state relationships. In the same time, one can recognize highly country-specific postal services provided by Japan Post via its digital platform. These special services reflect uniqueness of Japanese culture, and traditions.

Another section is utilization of postal services offered via digital platforms for e-government purposes. This is perceived as a natural evolution of communication between a modern state and a citizen in the age of Internet. In this regard statistics on saturation by digital platforms and utilization of digitalization potential seem most informative. US is the leader here, with EU quickly catching up. 
A big question remains on the extent to which modern solutions affect environment. Utilization of electronic equipment and digital platforms is a source of savings in terms of money for all agents involved. This is also a way to protect the natural environment against pollution, waste (of paper), and greenhouse gases emissions. According to our study, some countries and societies seem to be working effectively towards this end, achieveing tangible results in both, cost savings and reduced impact on the environment. The current situation leaves still great deal of improvement in some regions, as national post operators do not fully utilize the available IT solutions.

An advantage of national postal operators when it comes to coverage of digital platforms results from the fact that national posts have the largest distribution networks (i.e. post offices and postmen). This backgroud guarantees reaching all citizens, not only those who use Internet, but also those who are digitally excluded (older ones and in remote areas). Role of national posts is significant. Most EU citizens have confidence in national operators and recognise their brand. The most valued features of post office services are security, fairness and efficiency (Opinions 2016). For implementation of digital boxes for public administration and citizens to succeed, three basic conditions must be met. First, the focus should be on a single system, a single digital platform for public administrations and a postal operator of an EU country, without any government-operated alternatives. A successful example is e-Boks in Denmark. An unsuccessful one is Italian Post Office's digital mailbox that was closed down because the PEC system run by Italian government was more popular. Second, the functionality of a digital platform is important. This means that the system must offer an intuitive interface easy-to-use. Third, support from a government and priority must be given to digital administration. A good model of using postal infrastructure for the digital state is the solution present in the Czech Republic. Services provided by digital platforms should be based on public interest rather than economic individualism, or market-based approach. These services, like postal services, provide public value. Governments should ensure that all citizens in a country have access to high-quality digital services, free of charge, anywhere, and under the same conditions. Hence, any digital platform for communication and interaction between the state and citizens should be maintained by government, or postal national operator.

The current research on digital platforms seem to suffer no limitations due to full relevant information available in the real time. However, as the new forms of communication are developed and introduced by national postal operators in Europe and Asia, further research may bring new insights into leadership position in this regard.

\section{References}

Atlantico (2016). Retrieved February 28, 2018 from http://www.atlantico.fr/decryptage/fermeture-annoncee-site-monservice-publicfr--ou-comment-simplification-rapports-entre-administration-et-administres-heure-2675563.html

Castells, M. (2010). The rise of the network society, Malden, MA: Wiley-Blackwell.

Cetina, K. and Bruegger, K. (2002). Global Microstructures: The Virtual Societies of Financial Markets. American Journal of Sociology. 107, no. 4, pp. 905950. https://doi.org/10.1086/341045

Chaffey, D. (2016). Digital business i e-commerce management. PWN, Warszawa.
Communication from the Commission to the European Parliament, the Council, the European Economic and Social Committee and the Committee of the Regions, Brussels, COM(2016) 179 final. Retrieved 28 February 2019 from http://ec.europa.eu/transparency/ regdoc/rep/1/2016/EN/1-2016-179-EN-F1-1.PDF.

Czech Post (2018). Description of Datove Schranky system. Retrieved February 28, 2019 from https:// www.datoveschranky.info

Czech Post (2018). Operational guide for individual Datove Schranky account. Retrieved February 28, 2019 from https://www.mojedatovaschranka.cz/

Danish Post (2018). E-Boks system and financial ser- 
vices. Retrieved February 28, 2019 from https://www.e-boks.com/corporate/en/loesninger

Danish Post (2018). History and operations of e-Boks system. Retrieved February 28, 2019 from http://www.e-boks.dk/privat/senders.aspx

Danish Post (2018). Instruction how to use e-Boks. Retrieved February 28, 2019 from https://min.e-boks.dk/help_overview.aspx\#t3015de93-4bb2-47a3-a9da-e1cddbc74aa1

Digitization of the B2B market. [Digitization of the B2B market]. Retrieved February 28, 2019 from https:// www2.deloitte.com/content/dam/Deloitte/pl/Documents/Reports/pl_Raport_Aleo_Deloitte_2016_ONLINE_01.pdf

EU Commission (2015). A Digital Single Market Strategy for Europe (2015), European Commission , Communication from the Commission to the European Parliament, the Council, the European Economic and Social Committee and the Committee of the Regions, Brussels,\{SWD(2015) 100 final\}. Retrieved February 28, 2019 from https://ec.europa.eu/digital-single-market/en/news/digital-single-market-strategy-europe-com2015-192-final

EU Commission (2016). Digitizing European Industry (2016), Reaping the full benefits of a Digital Single Market, Communication from the Commission to the European Parliament, the Council, the European Economic and Social Committee and the Committee of the Regions, Brussels 19.4.2016, COM(2016) 180 final. Retrieved February 28, 2019 from http://ec.europa. eu/newsroom/dae/document.cfm?doc_id=15267

EU Commission (2016). ICT Standardisation Priorities for the Digital Single Market, Communication from the Commission to the European Parliament, the Council, the European Economic and Social Committee and the Committee of the Regions, Brussels, COM(2016) 176 final. Retrieved February 28, 2019 from http://ec.europa.eu/newsroom/dae/document. cfm?doc_id=15265

EU Commission (2016). Online Platforms and the Digital Single Market Opportunities and Challenges for Europe(2016), European Commission , Communication from the Commission to the European Parliament, the Council, the European Economic and Social Committee and the Committee of the Regions \{SWD(2016) 172 final\}, Brussels, 25.5.2016, COM(2016) 288 final. Retrieved February 28, 2019 from https://ec.europa.eu/digital-single-market/en/ news/communication-online-platforms-and-digital-single-market-opportunities-and-challenges-europe

EU eGovernment Action Plan 2016-2020 (2016). Accelerating the digital transformation of government,

French Government (2018). Gateway to public services platform. Retrieved February 28, 2019 from https://www.service-public.fr

Gajewski J., Paprocki W. and Pieriegud, J. (2016). Cyfryzacja gospodarki społeczeństwa i wyzwania dla sektorów infrastrukturalnych [Digitisation of the economy and society. Opportunities and challenges for the infrastructure sectors]. G Instytut Badań nad Gospodarką Rynkową - Gdańska Akademia Bankowa, dańsk 2016.

Government of the Czech Republic (2018). New solutions in communication with Authorities. Retrieved February 28, 2019 from https://www.vlada.cz/en/ media-centrum/aktualne/novelties-in-communication-with-the-authorities-data-boxes-60252

Italian Post (2018). Announcement of closing digital platform. Retrieved February 28, 2019 from http:// www.giurdanella.it/2015/01/23/chiude-postacertificat-che-fine-fanno-le-caselle-attive

McKinsey (2016). Cyfrowa Polska. Retrieved February 28, 2019 from http://mckinsey.pl/wp-content/uploads/2016/08/Cyfrowa-Polska.pdf

McKinsey (2016). Cyfrowa Polska. Retrieved February 28, 2019 from http://mckinsey.pl/wp-content/uploads/2016/08/Cyfrowa-Polska.pdf

Office of Electronic Communications (2015). Analysis of prices of fixed-line Internet access services in Poland, Warszawa.

Office of Electronic Communications, (2016). Digital Poland - Report 2016. Warszawa

EU Commission (2014). On electronic identification and trust services for electronic transactions in the internal market and repealing Directive 1999/93/EC (2014), REGULATION (EU) No 910/2014 OF THE EUROPEAN PARLIAMENT AND OF THE COUNCIL.

Opinions on POLISH POST OFFICE S. A. (2016). Research Report, CBOS, Warszawa

Piskorski, K. (2016).Cyfryzacja usług publicznych w Europie. Rola Operatorów Pocztowych. [Digitisation of public services in Europe. The role of Postal operators], Instytut Pocztowy, Warszawa. 
Piskorski, K. (2017). E-Skrzynka i e-Doręczenie. Możliwy scenariusz dla Polski [E-box and E-delivery. The possible scenario for Poland], Instytut Pocztowy, Warszawa.

Polish Government (2017). Od papierowej do cyfrowej Polski [From paper to digital Poland] (2017). Ministerstwo Cyfryzacji. Retrieved February 28, 2019 from https://www.gov.pl/documents/31305/0/prezentacja_programu_od_papierowej_do_cyfrowej_polski_2.pdf/0f3d57c6-03b6-97ad-e8a6-14d26af30fbf

Polish Post (2018). Polish Post services via Internet. Retrieved February 28, 2019 from https://www.envelo.pl/?gclid=EAlalQobChMI1ZGlotvJ2QIVXc-yChOxhwLrEAAYASAAEgllzfD_BwE
Śledziewska, K. Włoch, R., Słók-Wódkowska, M., Mazur , J. Paliński, M., Svilwonik, M.(2017). Przewodnik po jednolitym rynku cyfrowym dla MŚP [Guide to the Single Digital Market for SMEs], DELab, Warszawa.

Sobczak, A. (2013). Koncepcja cyfrowej transformacji sieci organizacji publicznych. "Roczniki" Kolegium Analiz Ekonomicznych SGH. z. 29, Oficyna Wydawnicza SGH, Warszawa, ,p. 280.

Tian, Y. and Stewart C. (2006). History of E-Commerce , w: Encyclopedia of E-commerce, E-government, and Mobile Commerce, red. M. Khosrow-Pour, Idea Group Reference, London, p. 560.

Van Dijk, J. (2005). The Deepening Divide: Inequality in the Information Society. London: SAGE
About the authors

\author{
MACIEJ LEWANDOWSKI \\ $\mathrm{PhD}$ \\ Poczta Polska S.A., Pion Operacji \\ Logistycznych Region Dystryb \\ Fields of interests \\ Postal economics, logistics \\ Address \\ ul. Prokocimska 6, 30-900 \\ Kraków, Poland \\ maciej.lewandowski@ \\ poczta-polska.pl
}

\section{PAWE $Ł$ M ODKOWSKI}

PhD

School of International Liberal Arts, Miyazaki International College

\section{Fields of interests}

Theory of economics, transactions costs in GE models
Address
1405 Kano-hei, Kiyotake-cho, Miyazaki-shi, Miyazaki 889-1605 Japan pawel.mlodkowski@gmail.com

\section{MAREK WRÓBEL}

PhD

Poczta Polska S.A. and Instytut Naukowy Zarządzania, Wyższa Szkoła Bankowa w Chorzowie

\section{Fields of interests}

Postal economics

\section{Address}

Sportowa 29, 41-506 Chorzów, Poland

Marek.Wrobel@

katowice.poczta-polska.pl 